\title{
Resprouting ability and intensity after damage in seedlings of the large-seeded species Araucaria angustifolia
}

\section{Fernanda da Silva Alabarce ${ }^{1}$, Lucia Rebello Dillenburg ${ }^{1 *}$}

\author{
'Laboratório de Ecofisiologia Vegetal, Departamento de Botânica, Universidade Federal do Rio Grande do Sul, \\ Porto Alegre, RS, Brazil.
}

${ }^{*}$ Corresponding author: lucia.dillenburg@ufrgs.br

Received: June 4, 2012; Accepted: August 14, 2012

\begin{abstract}
The role of seed reserves on the ability to resprout and on the responses of resprouting in Araucaria angustifolia was investigated. Seedlings were separated into three groups: plants which had their shoot damaged, a similar group in which damaged plants had their connection to the supporting seed removed, and a control group. All damaged seedlings resprouted, but those which remained connected to their seeds had a greater mass of resprouted shoots than the ones disconnected from their seeds. A greater accumulation of seed mass in the underground hypocotyl was a very distinct initial response to damage, but, on the long run, damaged plants were able to reestablish a biomass allocation pattern, which was very similar to the control plants. These results indicate that seed and underground reserves are important for the quantitative resprouting response of seedlings of $A$. angustifolia and for its ability to reestablish the functional balance when severely damaged.
\end{abstract}

Keywords: Brazilian pine, herbivory, resource allocation, seed size, storage.

Abbreviations: C: control plants; D: damaged plants; DP: damaged plants disconnected from their seeds

\section{INTRODUCTION}

Resprouting in trees is an induced response to injury or to a dramatic change in the surrounding environmental conditions (Del Tredici, 2001). Defoliation, decapitation or partial removal of axillary buds stimulate the formation of adventitious buds (Barchuk et al., 2006), with consequent growth of a new branch. The ability to resprout may vary due to abiotic conditions, stored energy, age or size of the individual at the time of disturbance and meristematic activity (Bond and Midgley, 2003), and this activity differs greatly among species (Paciorek et al., 2000). It is a universal attribute of temperate angiosperm trees but it is much less common among gymnosperms (Del Tredici, 2001). However, species of the genera Agathis, Araucaria and Wollemia (Araucariaceae) have a unique axillary structure, consisting of undifferentiated axillary meristems, which are able to develop into buds when released from apical dominance, giving these conifers the ability to resprout after damage (Burrows, 1987; 1989; Burrows et al. 2003). Araucaria angustifolia (Bertol.) Kuntze (Brazilian Pine), the object of this study, is an indigenous critically endangered (IUCN, 2010) and very tall gymnosperm species from the highland plateaus of Southern Brazil, with such ability.

The resprouting of shoots is an efficient mean by which woody plants regain the biomass lost during disturbance (Bellingham, 2000). In tropical forests, for example, stump sprouts were shown to greatly contribute with the vegetative regrowth after fire (Knight, 1975; Kauffman, 1991). While resprouting in mature trees extends the lifespan of the individual following damage, resprouting in seedlings promotes their survival under a variety of 
stressful conditions, including suppression caused by canopy trees, herbivory, site exposure, and desiccation (Del Tredici, 2001). Araucaria angustifolia is the major tree component of the so called araucaria forests, which often form mosaics with adjacent grasslands (Overbeck et al., 2007). Besides colonizing the open, grassland environments (Duarte, 2006), it also regenerates in the forest understory, establishing seedling banks (Duarte et al., 2002). Fire, cattle grazing, and herbivory (mostly by ants of the Acromyrmex crassispinus and Atta sp. species) are potential threats to seedling establishment in the open (Ferreira and Irgang, 1979; Zandavalli, 2006), while plant pathogens, small herbivores (such as the rodents Dasyprocta azarae and Akodon montensis), and logging activities are important threats in the forest (Zandavalli, 2006). Here, the presence of sprouts that emerge from stems of mature trees removed by logging has been commonly observed. However, the ability to resprout is also expressed by seedlings and very young plants. Multistemmed individuals, observed mostly in open areas (Mattos, 1994), have been associated with damage to the main stem, followed by resprouting, very early in the life of the trees (Zandavalli, 2006).

Successful resprouting depends on stored resources and, in cases in which disturbance causes loss of most aboveground biomass, mobilization of belowground resources is essential for this compensatory growth response (Bellingham, 2000). In the case of seedlings, seed storage might be especially relevant in resprouting. In fact, seed size has been found to be positively correlated with seedling tolerance to several unfavourable conditions such as shade, drought, fire, freezing and herbivory, because a greater amount of reserves increases the possibility of successful seedling establishment, as it enables survival for a longer period of time under these conditions (Haig and Westoby, 1991; Westoby et al., 1996; Leishman et al., 2000; Lahoreau, 2006). Brazilian pine has very large seeds (pine nuts), with $\sim 5$ to $8 \mathrm{~g}$ fresh weight (Tompsett, 1984). Most of the seed reserves are in the starchy female gametophyte (Panza et al., 2002), which is a very important food source for several animal species, some of which act both as seed predators and dispersers (Iob and Vieira, 2008). Brazilian pine seeds are recalcitrant (Panza et al., 2002) and promptly germinate after dispersion. Germination is hypogeal (Haines, 1983), though Burrows et al. (1992) have further classified its germination behaviour as cryptogeal. The cotyledons, usually two, elongate and partially emerge from the seed acting as haustoria, and transferring reserves from the starchy megagametophyte to the growing seedling (Rosado et al., 1994). Given the large seed size, the duration of use of its reserves by the seedlings is quite long (70 to 120 days), but it is not affected by the availability of light or nutrients (Lowe and Dillenburg, 2011). The swollen, tuber-like, underground hypocotyl (Figure 1) acts as an

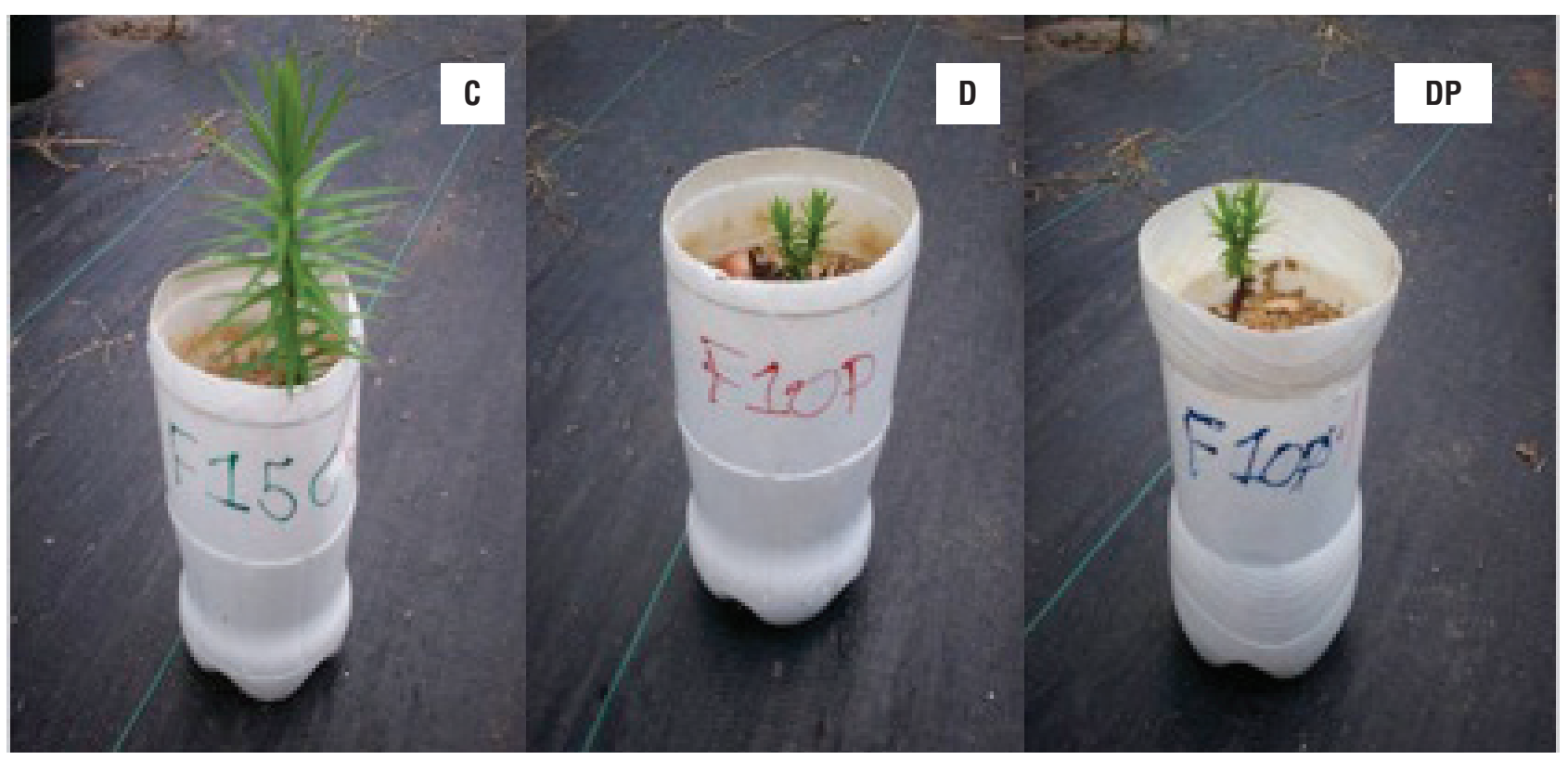

Figure 1. From left to right, the general aspect of a representative plant from the control (C), damaged (D) and damaged and disconnected from the seed (DP) groups. Pictures were taken 70 days after damage was imposed. 
important initial sink for at least some of the seed reserves (Dillenburg et al., 2010), and Lowe and Dillenburg (2011) have suggested that it may operate in a possible 'reserve effect' (Westoby et al., 1996) in this species. Thus, not only the seed, but also the hypocotyl storage, might be important to determine the successful sprouting of the seedlings after damage is caused to the aerial parts.

In this study, we conducted a greenhouse experiment in order to assess the ability and intensity of resprouting in damaged seedlings of $A$. angustifolia and the impact of internal carbon reserves on these processes. The answers to the following questions were pursued in this study: (1) Is the resprouting ability of damaged seedlings dependent on the reserves provided by the seeds? (2) Is the resprouting intensity of damaged seedlings affected by the availability of seed reserves? and (3) Do damaged seedlings increase the allocation of reserves available to the resprouting shoots?

\section{MATERIAL AND METHODS}

Seed germination and planting: Pine seeds were purchased from local seed gatherers in the town of São

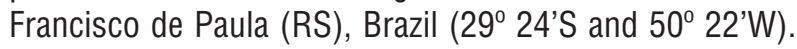
Prior to germination, seeds were disinfested with a $2 \%$ sodium hypoclorite solution for $20 \mathrm{~min}$, then rinsed with water and mechanically scarified by removing the external seed coverings from the radicle-protrusion region (Ferreira and Handro, 1979). Germination took place in trays containing wet vermiculite. On September 19, 2009, pre-germinated seeds were planted in 2.0L PET bottles, filled with medium-sized, pre-washed sand.

Growth conditions: The experiment was conducted in experimental gardens of the Agronomy School of Universidade Federal do Rio Grande do Sul (UFRGS), located in Porto Alegre (RS), Brazil (30 01'59"S and $\left.51^{\circ} 13^{\prime} 48^{\prime \prime} \mathrm{W}\right)$ for a period of approximately 6 months (September 2009 - March 2010). Plants were grown under naturally fluctuating conditions of temperature, air humidity and light and were well watered throughout the experiment.

Treatments and experimental design: After planting, all plants remained under the same conditions until they reached a height of approximately $50 \mathrm{~mm}$ ( 55 days after germination). This period is considered the day 0 of the experiment, when plants were separated into three groups: (1) C; (2) D; and (3) DP. C kept growing under the same existing conditions. Plants from the $D$ and
DP groups had about $80 \%$ of the stem length removed by means of a single cut made with a pair of scissors $10 \mathrm{~mm}$ above the hypocotyl. Most of the leaves ( 42 leaves) were removed and $\sim 8$ leaves remained at the stump. In addition to shoot damage, DP plants had their connection to the supporting seed broken by excising the cotyledons. At this stage of seedling development, seeds are still providing nutrients to the plants (Lowe and Dillenburg, 2011), and, in the particular case of this experiment, seeds had about $70 \%$ of the original dry mass when they were disconnected from DP plants. Each treatment group comprised 16 plants (experimental units), totaling 48 plants for the experiment.

Plant evaluations: Every 2 weeks we recorded the number of sprouts and the height of resprouted and control shoots. Three plant harvests for mass determination were scheduled during the experiment: 0,70 and 160 days after treatments were imposed, thus ensuring that the experiment would end after seed reserves were no longer sustaining seedling growth (Löwe and Dillenburg, 2011). On day 0 (when treatments were imposed), we harvested 9 ( 3 from each group) of the 48 plants available in order to determine the initial mass of different plant parts. The mass of the six plants belonging to the $\mathrm{D}$ and DP treatment already reflected the damage imposed to them. The 39 plants left after this first harvest were equally distributed among C, D, and DP plants. On days 70 and 160, we harvested six and seven plants from each group, respectively. Plant material was oven dried $\left(60^{\circ} \mathrm{C}\right)$ until constant weight. The masses of seed, cotyledons, shoot (or sprouts), tap root, lateral roots, and underground hypocotyl were separately recorded. The latter was recognized as being distinct from the main root not only by the lack of lateral roots, but also because of its enlargement and slightly different coloration (Dillenburg et al., 2010). Relative mass growth rates for the two time intervals (0-70 and 70-160 days) were calculated for each plant component, by dividing the mass accumulated (or depleted) in each period by the initial value of mass and number of days comprehended in that time interval. Positive values indicated growth or mass accumulation, and negative values, mass consumption.

Statistical analysis: The single factor ANOVA was used to compare resprouting parameters and biomass partitioning among treatments in each evaluation period. The effects of treatment (C, D, and DP) and time (days 0,70 , and 160) on plant mass and of treatment (C, D, and DP) and time interval (0-70 and 70-160) on relative growth rates were assessed using two-way ANOVA. After the ANOVA procedures, individual means were compared by the Tukey's procedure at $p \leq 0.05$. ANOVA and mean 
separation procedures were run with the statistical package Statistix 8.0 (Analytical Software).

\section{RESULTS}

Resprout ability: All damaged seedlings resprouted and survived, regardless of whether they remained connected to the supporting seed or not (Figure 1). The first sprouts emerged from lateral buds 20 days after seedlings had been damaged. Out of all resprouted plants ( $D$ and DP), three produced only one sprout, and, for those that produced more than one, $39 \%$ showed dominance of one sprout, while $61 \%$ had sprouts with similar heights. This pattern was the same in both groups of $D$. The number of sprouts per plant and the mean mass and height of each sprout did not differ between D and DP plants. However, the total mass of sprouts per plant, measured 160 days after damage, was significantly greater in seedlings that remained connected to their seeds (D) than in those that did not (DP) (Table 1).

Resprout intensity: both time and treatment significantly affected most of the masses and relative growth rates of the different seedling components, and, in most cases, these two factors significantly interacted with one another (Table 2).

Seventy days after damage, the shoot mass of $D$ and DP plants was not yet significantly different from their respective initial masses, and was much lower than that of the undamaged $C$ (Figure 2A). Root mass, on the other hand, did not increase significantly between

Table 1. Sprout growth measurements of $A$. angustifolia seedlings 70 and 160 days after their shoots were damaged. Data are means $( \pm S E)$. Means were compared within each period of time, and different letters indicate significant differences $(p \leq 0.05)$ between damaged plants (D) and plants which were both damaged and disconnected from their seeds (DP); $n=6-7$, for 70 and 160 days, respectively.

\begin{tabular}{lcccc}
\hline $\begin{array}{l}\text { Treatment/days after } \\
\text { damage }\end{array}$ & $\mathbf{N}^{\mathbf{0}}$ sprouts & Sprout height (mm) & Mass per sprout (g) & Sprouts total mass (g) \\
\hline D/70 & $2.3(0.4)$ & $27(5)$ & $0.06(0.02)$ & $0.13(0.03)$ \\
DP/70 & $2.5(0.2)$ & $22(2)$ & $0.04(0.01)$ & $0.08(0.01)$ \\
D/160 & $2.6(0.4)$ & $71(1)$ & $0.47(0.09)$ & $1.07(0.15) \mathrm{a}$ \\
DP/160 & $2.0(0.2)$ & $69(1)$ & $0.35(0.08)$ & $0.59(0.09) \mathrm{b}$ \\
\hline
\end{tabular}

Table 2. Results from two-way ANOVA of mass and relative growth rate parameters of Araucaria angustifolia seedlings.

\begin{tabular}{|c|c|c|c|c|c|c|c|c|c|}
\hline Mass & Source & DF & $F$ & $\mathrm{p}$-value & Growth Rates & Source & DF & $F$ & p-value \\
\hline & Treatment & 2 & 47.32 & 0.0000 & & Treatment & 2 & 1.75 & 0.2148 \\
\hline \multirow[t]{3}{*}{ Seedling } & Time & 2 & 75.45 & 0.0000 & Seedling & Time & 1 & 3.77 & 0.0759 \\
\hline & Treatment $x$ time & 4 & 19.10 & 0.0000 & & Treatment $x$ time & 2 & 0.60 & 0.5630 \\
\hline & Treatment & 2 & 62.30 & 0.0000 & & Treatment & 2 & 10.71 & 0.0021 \\
\hline \multirow[t]{3}{*}{ Shoot } & Time & 2 & 99.38 & 0.0000 & Shoot & Time & 1 & 27.43 & 0.0002 \\
\hline & Treatment $\mathrm{x}$ time & 4 & 15.02 & 0.0000 & & Treatment $\mathrm{x}$ time & 2 & 9.00 & 0.0041 \\
\hline & Treatment & 2 & 27.49 & 0.0000 & & Treatment & 2 & 21.01 & 0.0001 \\
\hline \multirow[t]{3}{*}{ Root } & Time & 2 & 56.49 & 0.0000 & Root & Time & 1 & 5.46 & 0.0376 \\
\hline & Treatment $x$ time & 4 & 22.44 & 0.0000 & & Treatment $x$ time & 2 & 12.03 & 0.0014 \\
\hline & Treatment & 2 & 13.33 & 0.0001 & & Treatment & 2 & 2.77 & 0.1025 \\
\hline \multirow[t]{3}{*}{ Cotyledon } & Time & 2 & 1.11 & 0.3426 & Cotyledon & Time & 1 & 0.19 & 0.6709 \\
\hline & Treatment $x$ time & 4 & 2.95 & 0.0369 & & Treatment $x$ time & 2 & 9.13 & 0.0039 \\
\hline & Treatment & 2 & 9.61 & 0.0006 & & Treatment & 2 & 1.69 & 0.2251 \\
\hline \multirow[t]{3}{*}{ Hypocotyl } & Time & 2 & 10.90 & 0.0003 & Hypocotyl & Time & 1 & 16.63 & 0.0015 \\
\hline & Treatment $\mathrm{x}$ time & 4 & 5.71 & 0.0016 & & Treatment $\mathrm{x}$ time & 2 & 9.09 & 0.0040 \\
\hline & Treatment & 1 & 0.25 & 0.6246 & & Treatment & 1 & 5.92 & 0.0474 \\
\hline \multirow[t]{2}{*}{ Seed } & Time & 2 & 16.83 & 0.0000 & Seed & Time & 1 & 5.9 & 0.0431 \\
\hline & Treatment $x$ time & 2 & 0.99 & 0.3842 & & Treatment $x$ time & 2 & 5.48 & 0.0473 \\
\hline
\end{tabular}

DF: degrees of freedom. 

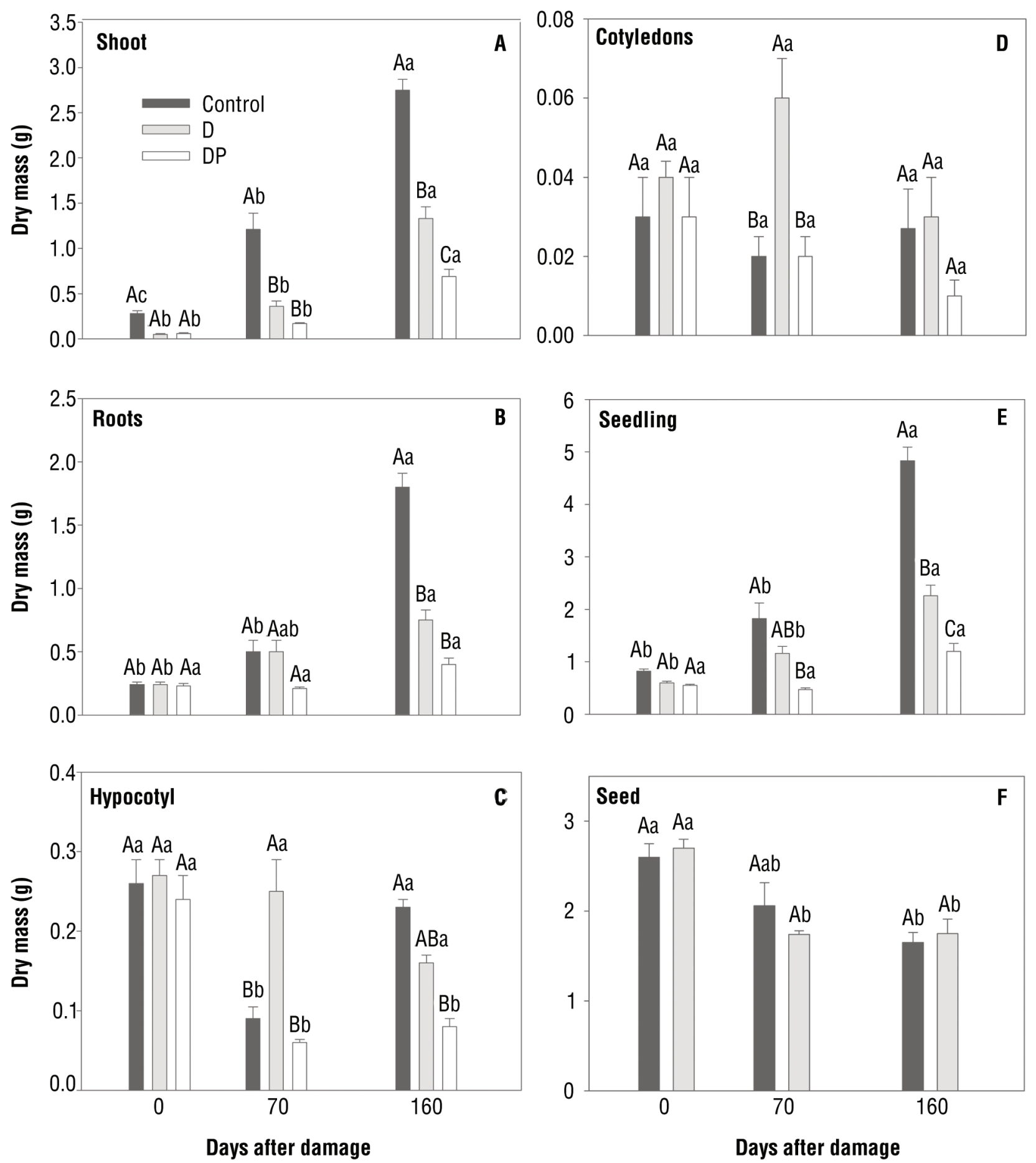

Figure 2. Accumulation of dry mass in different plant parts in seedlings of $A$. angustifolia. Vertical lines indicate standard errors of the means. Different uppercase letters indicate significant differences between treatments at a given time and different lowercase letters indicate significant differences between times within a given treatment $(n=3,6$, and 7 , for 0,70 , and 160 days, respectively). D: damaged plants; DP: damaged plants disconnected from their seeds. 
0 and 70 days for any of the plant groups (Figure 2B). While DP and $\mathrm{C}$ plants had a significant decrease of the hypocotyl mass in this initial period, D plants did not exhibit any mass depletion of this organ, maintaining significantly greater hypocotyl mass 70 days after damage in comparison to the other two treatments (Figure 2C). Cotyledon mass suffered insignificant variations between 0 and 70 days, but, at the end of this period, the cotyledon mass of $D$ plants was also significantly greater than in the other two treatments (Figure 2D). Variations in seedling mass greatly mirrored variations in shoot mass, but because of the contrasting response of $D$ plants regarding the hypocotyl, the overall seedling mass of these plants did not differ from the control after 70 days (Figure 2E). The relative growth (or consumption) rates during this initial period revealed a much higher shoot growth rate for the D plants than for the two other groups, as well as a much lower mass consumption rate of the hypocotyl of these plants than for the control and DP plants (Figures $3 A$ and $C$ ). The hypocotyl of these DP plants presented a significantly greater consumption rate than the controls (Figure $3 \mathrm{C}$ ), as well as a lower root growth rate (slightly negative) in relation to the other groups (Figure 3B). The overall seedling growth rate did not differ between treatments during this initial period (Figure 3E). Seeds supporting the growth of $D$ plants had a lower mass than those supporting the $C$ on day 70 , and the seed mass consumption rate for this initial period was greater for $D$ than for $\mathrm{C}$ plants (Figure 3F).

Between days 70 and 160, there was a significant increase in shoot mass in all treatments, but only $\mathrm{C}$ showed significant increase in total seedling mass. This mass was significantly greater in D than in DP plants, and much greater in control than in the other two groups (Figures $2 \mathrm{~A}$ and $\mathrm{E}$ ). Only $\mathrm{C}$ showed an increase in root mass in this second period (Figure $2 \mathrm{~B}$ ). There were no significant changes in the mass of cotyledons from day 70 to day 140, as well as no treatment effects on day 160 . The hypocotyl of the $C$ plants was the only one that significantly changed (increase) from day 70 to day 160 , resulting in greater hypocotyl mass for $C$ and $D$ than for DP plants. Seed mass did not suffer a further decrease in $D$ plants, and at the end of the experimental period, the mass remaining in the seeds of $C$ and $D$ plants was quite similar ( $46 \%$ of the original mass) (Figure $2 \mathrm{~F}$ ). There was a reduction in shoot growth rate for both $\mathrm{C}$ and $\mathrm{D}$ plants, compared to the first interval. These rates did not differ between the three groups in the second interval (Figure 3A). Root growth rate, on the other hand, increased for $\mathrm{C}$, which sustained a greater root growth rate between days 70 and 160 than the other two groups (Figure 3B). The consumption rate of hypocotyl of DP plants significantly reduced (values became less negative) from the first to the second interval, when all treatments had similar rates (Figure $3 \mathrm{C}$ ). As for the overall growth rate of the seedling, treatments once again did not differ from one another (Figure 3E). Seed consumption rate in this second interval was basically the same for $C$ and $D$ plants (Figure 3F).

Biomass partitioning after resprout: 0 n day 0 , when damage was imposed, biomass partitioning was quite similar among the three plant groups, except for the shoot investment, which was smaller in the $D$ and DP plants than in the control group because of shoot excision. While in $\mathrm{C}$ the greatest investment was those of the shoot and hypocotyl, in D the hypocotyl mass had the greatest investment to the overall seedling mass (Figure 4A, Table 3). On day 70, C still maintained a greater shoot investment than $\mathrm{D}$, and their hypocotyl and cotyledon investments were much lower than in D and DP plants. The only difference between the two groups of $D$ was the greater investment of hypocotyl in $D$ than in DP plants (Figure 4B, Table 3 ). At the end of the experimental period, shoot and root investments were quite similar among all treatments (Figure 4C, Table 3).

\section{DISCUSSION}

All plants that suffered shoot damage survived through resprouting, but the seedlings that were still connected to their seeds had more vigorous sprouts. The fact that the ability to resprout did not depend on the continuous connection with the supporting seed provides the answer to our first question: the ability of seedlings to resprout does not depend on the amount of seed reserves to which seedlings have access to. In addition to the carbon reserves present in the plant, another important factor that affects the resprout ability of a species is the meristematic activity (Bond and Midgley, 2003). As aforementioned, undifferentiated meristems are present in the leaf axils of $A$. angustifolia (Fink, 1983; Burrows, 1987), and those meristems in the axils of the leaves that remained in the plant after damage were certainly responsible for the resprout response that followed shoot excision and release from apical dominance. Thus, the ability of $A$. angustifolia to produce sprouts when damaged only depends on meristematic activity. The ability to resprout from the stem base after suffering severe damage was also reported for $A$. humboldtensis (Veillon, 1978), and the role of these axillary meristems in coppice and epicormic bud initiation in $A$. cunninghamii was demonstrated by Burrows (1990). 

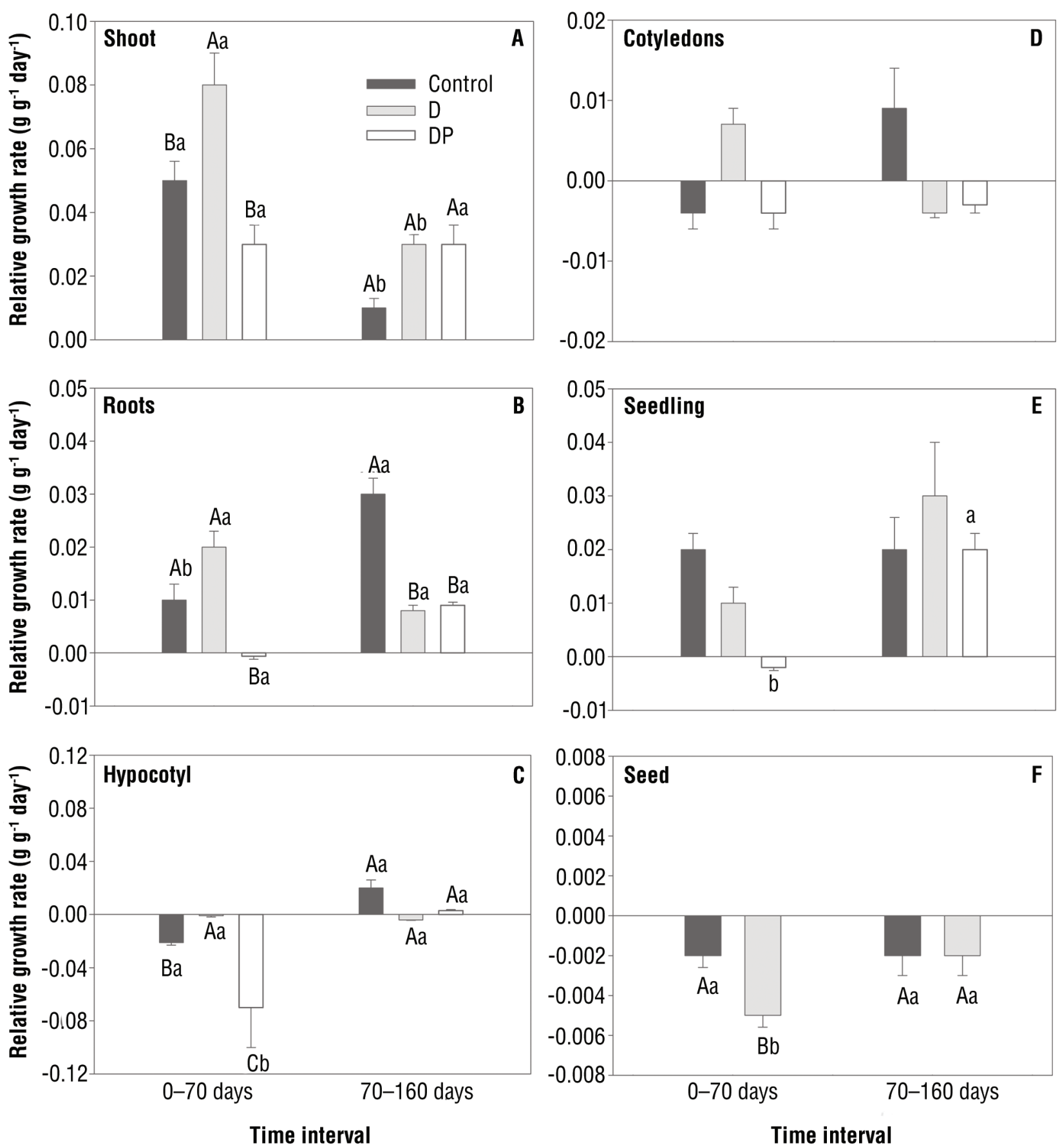

Figure 3. Relative growth rates of different plant components of seedlings of $A$. angustifolia. Positive values indicate actual growth or mass accumulation rates, and negative values indicate mass consumption rates. Vertical lines indicate standard errors of the means. Different uppercase letters indicate significant differences between treatments at a given time and different lowercase letters indicate significant differences between times within a given treatment $(n=3,6$, and 7 , for 0,70 , and 160 days, respectively). D: damaged plants; DP: damaged plants disconnected from their seeds. 
Although the number and height of sprouts were not affected by the amount of seed reserves, their mass was. Damaged seedlings with full access to the seed reserves
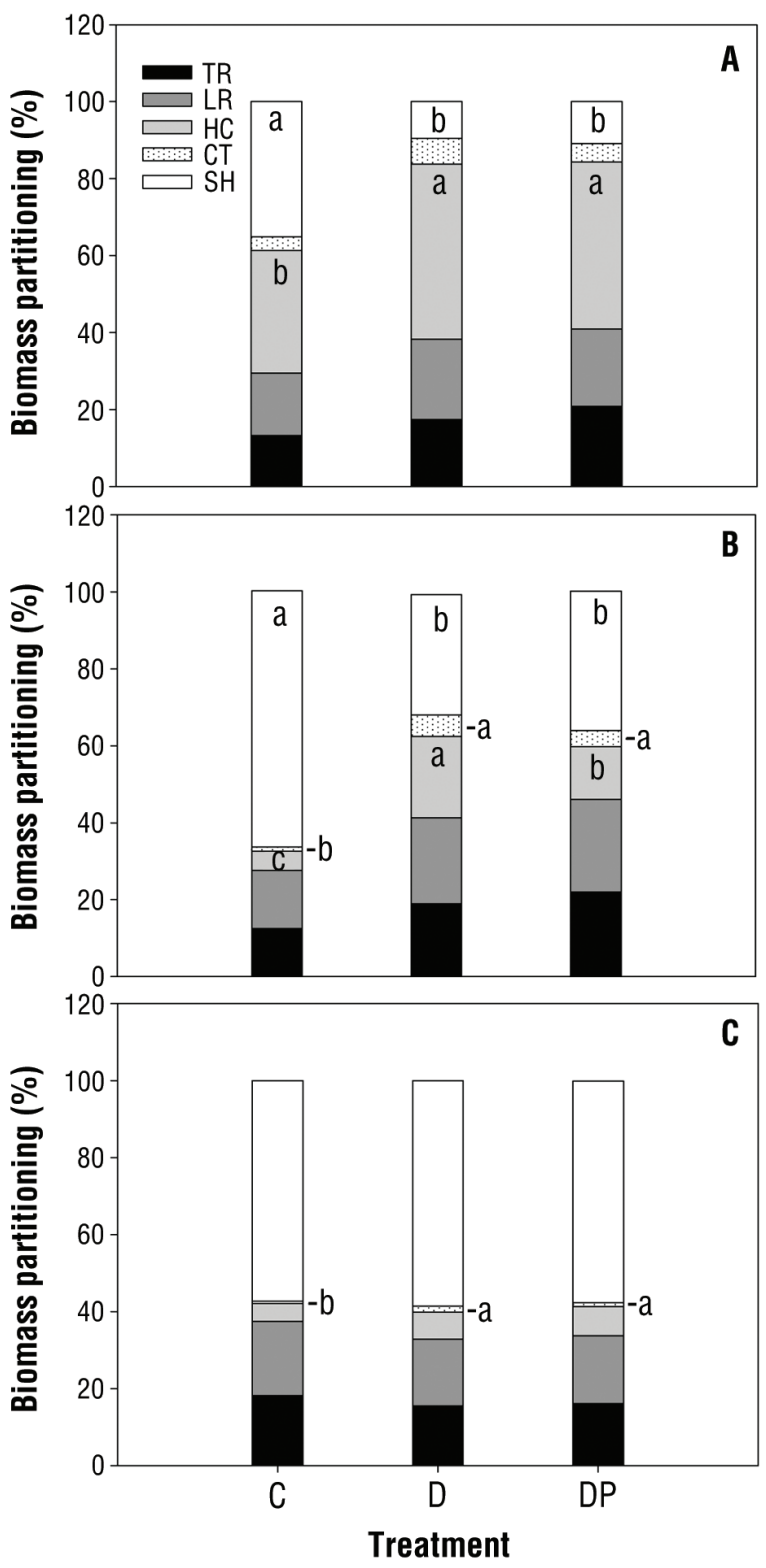

Figure 4. Biomass partitioning of different plant parts in seedlings of $A$. angustifolia at 0 (A), 70 (B) and 160 (C) days after damage application. Different letters indicate significant differences between treatments $(p \leq 0.05 ; n=3,6$, and 7 , for 0,70 , and 160 days, respectively). C: control plants; D: damaged plants; DP: damaged plants disconnected from their seeds; TR: tap root; LR: lateral roots; HC: hypocotyl; CT: cotyledons; SH: shoot. had sprouts with more mass than those without full access, which answers our second question: the resprout intensity of damaged seedlings is affected by the availability of seed reserves. Armstrong and Westoby (1993) have observed that larger seeded species can resprout and tolerate defoliation better than smaller seeded species. Larger seeds store more energy compounds and nutrients, and are known to provide not only better chances of plant survival under conditions of scarcity of resources, but also the replacement of photosynthetic tissues lost through herbivory or mechanical damage (Kidson and Westoby, 2000). The underground hypocotyl of $A$. angustifolia is an important initial sink of the seed reserves (Dillenburg et al., 2010), a fact which was also observed in this study. Since underground storage organs are commonly used for shoot replacement after defoliation event (Schutz et al., 2009), this seed-to-hypocotyl transfer may allow the species to hide its carbon-rich seed reserves from seed predators, ensuring its future use for seedling growth and tissue repair.

The day 0 of the present study coincided with the period of greatest accumulation of mass in the hypocotyl (55 days after germination), as reported by Dillenburg et al. (2010). This means that when shoot was severed much of the seed reserves that were to be transferred to the hypocotyl had already been transferred. Mass depletion of the hypocotyl between days 0 and 70 was quite evident in $\mathrm{C}$ and in those $\mathrm{D}$ which no longer had access to the seed reserves, a response also reported by Dillenburg et al. (2010) in undamaged seedlings.

Table 3. Results from one-way ANOVA of mass fractions of Araucaria angustifolia seedlings. Values of DF, $F$ and $p$-value are for the treatment effects.

\begin{tabular}{lcrc}
\hline Day/parameter & DF & $\boldsymbol{F}$ & p-value \\
\hline Day 0/TR & 2 & 1.36 & 0.2972 \\
Day 0/LR & 2 & 7.20 & 0.0100 \\
Day 0/HC & 2 & 37.73 & 0.0000 \\
Day 0/CT & 2 & 6.39 & 0.0144 \\
Day 0/SH & 2 & 35.26 & 0.0000 \\
Day 70/TR & 2 & 0.39 & 0.6875 \\
Day 70/LR & 2 & 0.60 & 0.5679 \\
Day 70/HC & 2 & 22.51 & 0.0001 \\
Day 70/CT & 2 & 9.51 & 0.0040 \\
Day 70/SH & 2 & 20.53 & 0.0020 \\
Day 160/TR & 2 & 0.16 & 0.8499 \\
Day 160/LR & 2 & 0.07 & 0.9333 \\
Day 160/HC & 2 & 0.05 & 0.9554 \\
Day 160/SH & 2 & 6.60 & 0.8100 \\
\hline
\end{tabular}

DF: degrees of freedom; TR: tap root; LR: lateral roots; HC: hypocotyl; CT: cotyledons; SH: shoot. 
Interestingly, however, this mass consumption was very much delayed in D, which were still being 'fed' by their seeds. Compared to controls, these plants also showed a greater consumption of seed reserves after damage was imposed. Lowe and Dillenburg (2011) have demonstrated that the rate of seed consumption is not affected by the availability or external resources such as light and nutrients, and they interpreted this behavior as the species strategy not to slow down seed-to-seedling transfer of storage material when seedling growth is limited by these resources, in order to reduce the chances of losing this material through seed predation. The results of the present study suggest that seedling herbivory might accelerate such transfer. This response should increase the chances that seed material will be available (mostly in the seedling hypocotyl) to help replace tissue loss. It should be noted that although seeds still retained $\sim 46 \%$ of their initial mass at the end of the experimental period, this does not imply that reserves were still available for seedling growth. This apparently high value is greatly due to the fact that seed mass included all seed coverings and not only the starchy megagametophyte. Lowe and Dillenburg (2011) demonstrated that $\sim 140$ days after seed sowing, seed megagametophyte was reduced to $13 \%$ of its initial mass and no longer sustained seedling growth. In the case of seedlings, which were prematurely disconnected from their seeds, the hypocotyl storage material that had already been removed from the seed before being separated from the seedling was the only resource to replace the lost photosynthetic tissues, and seeds were no longer available to provide additional resources to hypocotyl and root growth.

Regarding the third and last question posed in our study, the damaged seedlings did increase their investment in shoot growth when still connected to the supporting seeds, as indicated by their greater shoot mass relative growth rate when compared to undamaged seedlings during the first seventy days after shoot damage took place. A similar response was not observed for root growth. However, in these plants there was less photosynthetic tissue left and also a greater investment in hypocotyl storage. These may explain why, despite occurring at a very early stage of seedling growth and even though it induces a shoot compensatory growth, shoot damage caused seedlings to lag much behind the $\mathrm{C}$ in terms of overall seedling biomass throughout the experimental period, even when they were still connected to the supporting seed.

At the end of the experimental period, the pattern of biomass partitioning among the different plant organs was remarkably similar in all experimental plants. This means that $D$ progressively allocated more of their growth to shoots, demonstrating their ability to reestablish the pre-damage root:shoot ratio even after severe damage (Mihaliak and Lincoln, 1989). At the end of the experiment, the three groups of plants still showed large mass allocation to underground structures ( $40 \%)$, with much of this mass being allocated to the hypocotyl and main tap root ( 23\%). Large root systems and great allocation to carbohydrate root storage are associated to species that sprout when damaged (Sakai and Sakai, 1998; Schwilk and Ackerly, 2005). In the particular case of $A$. angustifolia seedlings, hypocotyl also contributes with this underground storage. However, we have only followed the species response to shoot damage through the seedling stage. Future approaches should include the ontogeny of such responses as well as the relative contribution of hypocotyl and roots in carbohydrate storage.

The results from this study have shown that seed and underground reserves are important for the quantitative resprout response of seedlings of $A$. angustifolia. Resprouting by seedlings is specially relevant for the regeneration of a tree species and, in the particular case of A. angustifolia, it adds another ecological significance to its large seeds. If deprived from their seeds at an early stage of seedling development, damaged seedlings will be able to sprout and attain a functional balance of their organs, but will be much smaller than those that still count on seed reserves, thus potentially becoming less competitive and tolerant to different environmental stresses. Considering that the species both regenerates itself in the forest understory and colonizes the open grassland environment, it would also be relevant in the future to investigate the role of light availability in the seedling environment to its resprout response.

Acknowledgements: We thank the Agronomy School of UFRGS for the greenhouse space. We also thank the Brazilian Council for Scientific and Technological Development (CNPq/Brazil) for fellowships awarded to the authors.

\section{REFERENCES}

Armstrong DP, Westoby M (1993) Seedlings from large seeds tolerate defoliation better: a test using phylogenetically independent contrasts. Ecology 74:1092-1100.

Barchuk AH, Campos EB, Oviedo C, Díaz MP (2006) Supervivencia y crecimiento de plántulas de especies leñosas del Chaco Árido sometidas a remoción de la biomas aérea. Ecol. Austral 16:47-61.

Bellingham PJ (2000) Resprouting as a life history strategy in woody plant communities. Oikos 89:409-416. 
Bond WJ, Midgley JJ (2003) The evolutionary ecology of sprouting. Int. J. Plant Sci. 164:103-114.

Burrows GE (1990) The role of axillary meristems in coppice and epicormic bud initiation in Araucaria cunninghamii. Bot. Gaz. 151:293-301.

Burrows GE (1989) Developmental anatomy of axillary meristems of Araucaria cunninghamii released from apical dominance following shoot apex decapitation in vitro and in vivo. Bot. Gaz. 150:369-377.

Burrows GE (1987) Leaf axil anatomy in the Araucariaceae. Austr. J. Bot. $35: 631-640$.

Burrows GE, Boag TS, Stockey RA (1992) A morphological investigation of the unusual cryptogeal germination strategy of bunya pine (Araucaria bidwillii) - an Australian rain forest conifer. Int. J. Plant Sci. 153:503-512.

Burrows GE, Offord CA, Meagher PF, Ashton K (2003) Axillary meristems and the development of epicormic buds in Wollemi pine (Wollemia nobilis). Ann. Bot. 92:835-844.

Del Tredici P (2001) Sprouting in temperate trees: a morphological and ecological review. Bot. Rev. 67:121-140.

Dillenburg LR, Rosa LM, Mósena M (2010) Hypocotyl of seedlings of the large-seeded species Araucaria angustifolia: an important underground sink of the seed reserves. Trees 24:705-711.

Duarte LS, Dillenburg LR, Rosa LMG (2002) Assessing the role of light availability in the regeneration of Araucaria angustifolia (Araucariaceae). Austr. J. Bot. 50:741-751.

Duarte LS (2006) Role of nurse plants in Araucaria Forest expansion over grassland in south Brazil. Austral Ecol. 31:520-528.

Ferreira AG, Handro W (1979) Aspects of seed germination in Araucaria angustifolia (Bert.) 0. Ktze. Rev. Bras. Bot. 2:7-13.

Ferreira AG, Irgang BE (1979) Regeneração natural de Araucaria angustifolia nos Aparados da Serra-RS. In: Congresso Nacional de Botânica. Anais, Rio de Janeiro, pp.225-230.

Fink S (1983) The occurrence of adventitious and preventitious buds within the bark of some temperate and tropical trees. Am. J. Bot. 70:532-542.

Haig D, Westoby M (1991) Seed size, pollination casts and angiosperm success. Evol. Ecol. 5:231-247.

Haines RJ (1983). Embryo development and anatomy of Araucaria Juss. Austr. J. Bot. 31:125-140.

Iob G, Vieira EM (2008) Seed predation of Araucaria angustifolia (Araucariaceae) in the Brazilian Araucaria Forest: influence of deposition site and comparative role of small and 'large' mammals. Plant Ecol. 198:185-196.

IUCN Red List of Threatened Species [Homepage da Internet]. [Cited 2012 Ago 31] Available at: www.iucnredlist.org

Kauffman JB (1991) Survival by sprouting following fire in tropical forests of the Eastern Amazon. Biotropica 23:219-224.

Kidson R, Westoby M (2000) Seed mass and seedling dimensions in relation to seedling establishment. Oecologia 125:11-17.
Knight DH (1975) A phytosociological analyses of species-rich Tropical Forest on Barro Colorado Island, Panama. Ecol. Monogr. 45:259-289.

Lahoreau G, Barot S, Gignoux J, Hoffmann WA, Setterfield SA, Williams PR (2006) Positive effect of seed size on seedling survival in fire-prone savannas of Australia, Brazil and West Africa. J. Trop. Ecol. 22:719-722.

Leishman MR, Wright IJ, Moles AT, Westoby M (2000) The evolutionary ecology of seed size. In: Fenner M (ed.), Seeds - Ecology of Regeneration in Plant Communities. CAB International, Wallingford, pp.31-57.

Löwe TR, Dillenburg LR (2011) Changes in light and nutrient availabilities do not alter the duration of use of seed reserves in Araucaria angustifolia seedlings. Austr. J. Bot. 59:32-41.

Mattos JR (1994) 0 pinheiro brasileiro. 2a. ed. Artes Gráficas Princesa, Lages.

Mihaliak CA, Lincoln DE (1989) Plant biomass partitioning and chemical defense: Response to defoliation and nitrate limitation. Oecologia 80:122-126.

Overbeck GE, Müller SC, Fidelis A, Pfadenhauer J, Pillar VD, Blanco CC, et al. (2007) Brazil's neglected biome: the South Brazilian Campos. Perspect. Plant Ecol. 9:101-116.

Paciorek CJ, Condit R, Hubbell P, Foster RB (2000) The demographics of resprouting in tree and shrub species of a moist tropical forest. J. Ecol. 88:765-777.

Panza V, Láinez V, Maroder H, Prego I, Maldonado S (2002) Storage reserves and cellular water in mature seeds of Araucaria angustifolia. Bot. J. Linn. Soc. 140:273-281.

Rosado RM, Ferreira AG, Mariath JEA, Cocucci AE (1994) Amido no megagametófito de Araucaria angustifolia (Bert.) 0. Kuntze: degradação durante a germinação e desenvolvimento do esporófito. Acta Bot. Bras. 8:35-43.

Sakai A, Sakai S (1998) A rest for the resource remobilization hypothesis: tree sprouting using carbohydrates from above-ground parts. Ann. Bot. 82:213-216.

Schwilk DW, Ackerly DD (2005) Is there a cost to resprouting? Seedling growth rate and drought tolerance in sprouting and nonsprouting Ceanothus (Rhamnaceae). Am. J. Bot. 92:404-410.

Schutz AEN, Bond WJ, Cramer MD (2009) Juggling carbon: allocation patterns of a dominant tree in a fire-prone savanna. Oecologia 160:235-246.

Tompsett PB (1984) Desiccation studies in relation to the storage of Araucaria seed. Ann. Appl. Biol. 105:581-586.

Veillon JM (1978) Architecture of the New Caledonian species of Araucaria. In: Tomlinson PB, Zimmermann MH (eds), Tropical trees as living systems. Cambridge University Press, Cambridge, pp.233-245.

Westoby M, Leishman MR, Lord JM (1996) Comparative ecology of seed size and dispersal. Phil. Trans. R. Soc. London. 351:1309-1318.

Zandavalli RB (2006) Importância da competição durante 0 estabelecimento e crescimento inicial da Araucaria angustifolia, Universidade Federal do Rio Grande do Sul. Tese de Doutorado. 